\title{
Evaluation of Groundwater Potentials of the Calabar Coastal Aquifers
}

\author{
E. A. $\mathrm{Amah}^{1}$, A. N. Ugbaja ${ }^{1} \&$ E. O. Esu ${ }^{1}$ \\ ${ }^{1}$ Department of Geology, University of Calabar, Calabar, Nigeria \\ Correspondence: E. A. Amah, Department of Geology, University of Calabar, Calabar, Nigeria. E-mail: \\ amahedet@yahoo.com
}

Received: July 9, 2012 Accepted: July 25, 2012 Online Published: August 17, 2012

doi:10.5539/jgg.v4n3p130 URL: http://dx.doi.org/10.5539/jgg.v4n3p130

\begin{abstract}
This article presents the results of groundwater site evaluation scheme and quality assessment of coastal aquifers in Calabar, South-eastern Nigeria based on ground water potential index (GWPI) scale, developed for this study. The GWPI consists of ten input parameters, namely: lithofacies (L), aquifer thickness (b), transmissivity (T), storativity (S), specific capacity (SC), static water level (SWL), formation resistivity (FR), chloride (Cl) contents, total dissolved solids (TDS) and Escherichia coli (E-coli). The groundwater potential index (GWPI) is computed as the sum of the products of weights and ratings assigned to each of the input parameters. The GWPI index varying between 20 and 60, is divided into three classes: high ( $>40)$, medium $(30-40)$, and low $(<30)$. The GWPI index, is then used to demarcate the study area into three hydrogeologic ground water potential zones. These are:

(i) Northern zone 1 (transitional, low GWPI)

(ii) Central zone 2 (coastal plain sands, high GWPI)

(iii) Southern zone 3 (coastal alluvium, medium GWPI).

The central zone 2 has the highest GWPI rating. The implication of this rating is that the aquifers in the central and southern zones 2 and 3 are more prolific water bearing than the transitional zone 1 that lies between the Coastal Plain Sands and the argillaceous sediments of the Calabar Flank. This is in agreement with the mean specific capacity (SC) and transmissivity (T) recorded for the central $\left(355.6 \mathrm{~m}^{3} / \mathrm{d} / \mathrm{m}, 2640 \mathrm{~m}^{2} / \mathrm{d}\right)$; southern $(150.0 \mathrm{~m} / \mathrm{d} / \mathrm{m}$; $\left.2150 \mathrm{~m}^{2} / \mathrm{d}\right)$ and northern $\left(52.1 \mathrm{~m}^{3} / \mathrm{d} / \mathrm{m}, 750 \mathrm{~m}^{2} / \mathrm{d}\right)$ zones respectively. Lithofacies, saturated thickness of the aquifer, static water level, transmissivity and storativity are the most important parameters which influence ground water availability in the study area. The GWPI results further reveal that E-coli (3-50 counts/100ml), chloride $\left(\mathrm{Cl}^{-}\right)$ $(2.5-21.0 \mathrm{mg} / \mathrm{l})$ and static water level $(\mathrm{SWL})(2.3-28.7 \mathrm{~m})$ remain the most significant parameters that contribute to groundwater pollution particularly in the southern zone of the study area. In the near future, water quality in aquifer will be affected due to poor management of human waste-disposal/salt water intrusion, thereby limiting the availability of potable water for domestic and industrial uses.
\end{abstract}

Keywords: groundwater, evaluation, GWPI, Calabar

\section{Introduction}

Groundwater is the major source of potable water in Calabar and its environs, South-eastern Nigeria. Hundreds of boreholes have been drilled by private firms, individuals and government agencies such as the Cross River State Water Board (CRSWB), Rural Water Supply and Sanitation (RUWASSA) to provide the teaming population with potable water. However, the sitting and installation of these boreholes were done mostly on wildcat basis without rigorous geological, hydrogeological /geophysical and technical planning. These factors have led to the high rate of borehole failure in the study area. The supply of good quality water in the area remains grossly inadequate (Amah, 2007). In order to demarcate areas of groundwater availability and groundwater pollution potential, a site evaluation scheme and quality assessment called groundwater potential index (GWPI) have been developed for the Calabar area.

The GWPI is a point count index method modified after some existing aquifer vulnerability methods such as DRASTIC and CALOD to produce groundwater potential/vulnerability maps. These maps are designed to show respective areas of greatest potential for prolific groundwater availability / contamination on the basis of hydrogeologic and anthropogenic (human) factors. DRASTIC is an acronym for the seven factors considered in the method: Depth to water, net Recharge, Aquifer media, Soil media, Topography, Impact of vadose zone media 
and hydraulic Conductivity of the aquifer (Aller et al., 1987). CALOD is derived from Clay layer thickness (C), Aquifer media character (A), Lateritic layer thickness (L), Overlying layer character (O) and the Depth to groundwater level (D) (Edet, 2004). The factors which influence groundwater availability are most likely to influence its pollution potential. DRASTIC and CALOD methods are modified by the GWPI factors and used as a site evaluation model and groundwater quality assessment method. The GWPI consists of ten input parameters namely: lithofacies (L), aquifer thickness (b), transmissivity (T), storativity (S), specific capacity (SC), static water level (SWL), formation resistivity (FR), Chloride ( $\mathrm{Cl}^{-}$), total dissolved solids (TDS) and Escherichia coli (E-coli).

In the study area, few of the published works have been on location of aquifers and borehole sitting using electrical resistivity (Edet, 1993; Okereke et al., 1998; Okon-Umoren, 1999) as well as delineation of Coastal Plain Sands into upper and lower aquifers (Edet \& Okereke, 2002; Amah \& Esu, 2008). Edet (2004) on the basis of CALOD index concluded that the upper aquifer was more vulnerable to surface contaminants than the lower aquifer. This paper describes how GWPI has been used as a site evaluation model and pollution index to demarcate the study area into groundwater potential zones.

\subsection{Location and Geology of Study Area}

The study area lies between latitudes $4^{\circ} 45^{\prime} \mathrm{N}$ and $5^{\circ} 15^{\prime} \mathrm{N}$ and longitudes $8^{\circ} 05^{\prime} \mathrm{E}$ and $8^{\circ} 45^{\prime} \mathrm{E}$. It covers the Calabar South, Calabar Municipality, Akpabuyo and parts of Odukpani Local Government Areas of the Cross River State (Figure 1). The Calabar area belongs to the lowland and swampland of South-eastern Nigeria (Iloje, 1991). Elevations, here are generally less than $100 \mathrm{~m}$ above the mean sea level. Three main rivers dominate the landscape of the study area. These are the Calabar, Great Kwa and Akpayafe rivers - flowing southwards into the Cross River. The climatic data show that the monthly temperature varies between $23.1^{\circ} \mathrm{C}$ and $28.7^{\circ} \mathrm{C}$ and the monthly precipitation varies from a low of $26.7 \mathrm{~mm}$ (February) to a high of $459.1 \mathrm{~mm}$ (July) (Edet \& Okereke, 2002).

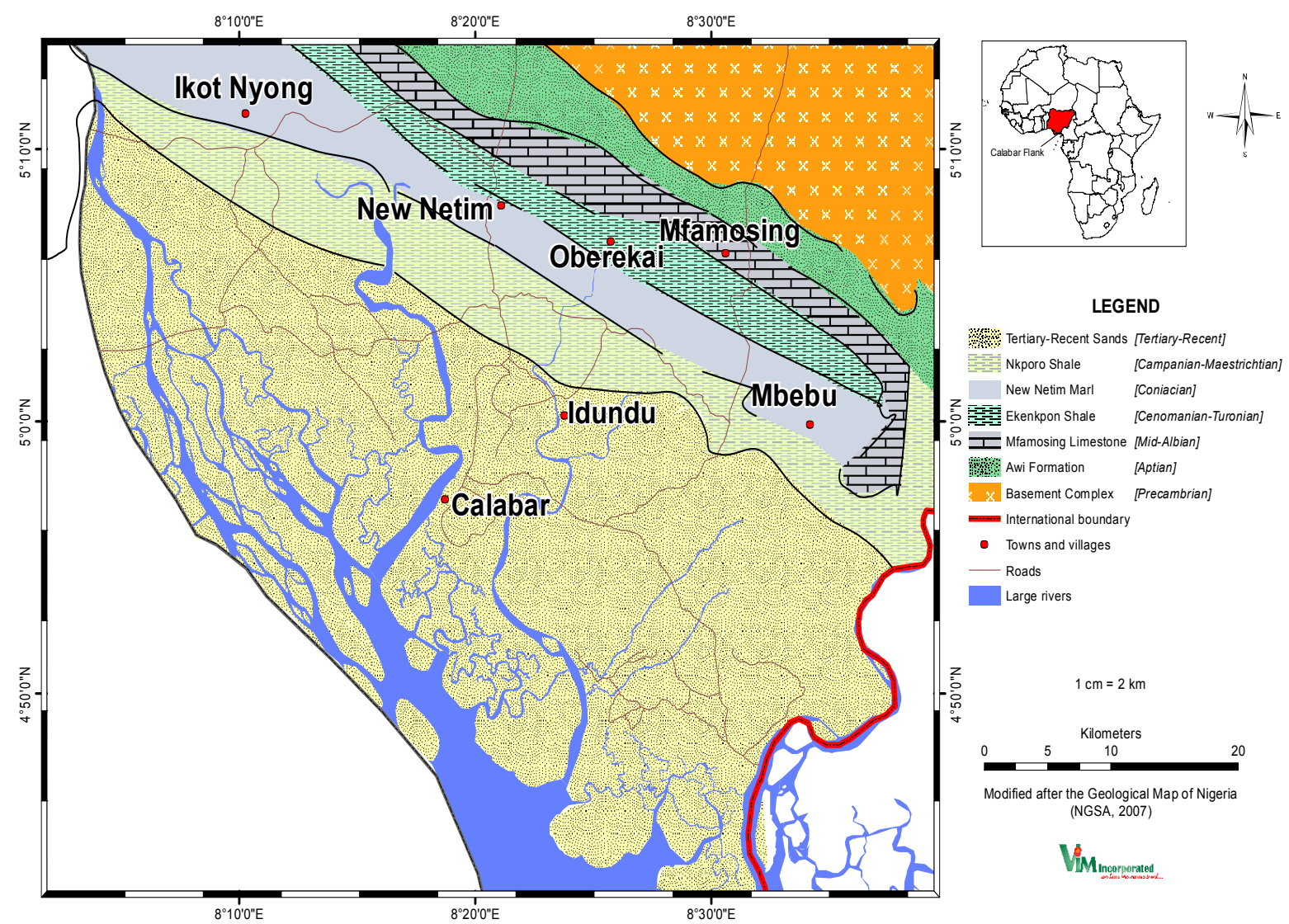

Figure 1. Geologic map of the study area

Geologically, the area is composed of Tertiary to Recent, continental fluvialite sands and clays, known as the Coastal Plain Sands. This formation is characterized by alternating sequence of loose gravel, sand, silt, clay, lignite and alluvium (Short \& Stauble, 1967). It is underlain mostly by rocks of the Cretaceous Calabar Flank and 
pre-Cambrian Oban Massif (Figure 1). The Coastal Plain Sands (Benin Formation) is by far the most prolific aquiferous hydrogeologic settings in the area and all the water boreholes are located in this Formation (Esu \& Amah, 1999). Alluvial deposits aquifer overlies the Benin Formation in the Southern parts of the study area. Recently, (Edet \& Okereke, 2002; Amah \& Esu, 2008) identified two water bearing units within the Coastal Plain Sand of the area. These are upper gravelly sand aquifer (UGSA) and lower fine sand aquifer LFSA.

\section{Method of Study}

The data employed in this study (Table 1) were compiled from surveys carried out by the authors between 2005 and 2010 in co-operation with the water development agencies and private drilling companies. These include data from vertical electrical sounding (VES), litho-logic logs, pumping tests and water quality. The details of all the techniques are found in (Amah, 2007; Amah \& Esu, 2008).

Forty-six Schlumberger vertical electrical sounding (VES) of maximum electrode spacing $\mathrm{AB}=1000 \mathrm{~m}$ were conducted in fairly well distributed locations within Calabar and environ for delineation and hydro-stratigraphic correlation of Coastal Plain Sand aquifers. Concurrently with the geophysical investigations, depths to water table and pumping test of wells were undertaken to determine their hydraulic parameters. Water samples from existing boreholes were also collected and tested for water quality. VES measurements were done with the aid of the ABEM Terrameter SAS 300B. The VES points and borehole locations were accurately surveyed using the Garmin 76 Global Positioning System (GPS) to obtain their latitude and longitude as well as the relative elevation data. The sampled localities are presented in Figure 2 and Table 1.

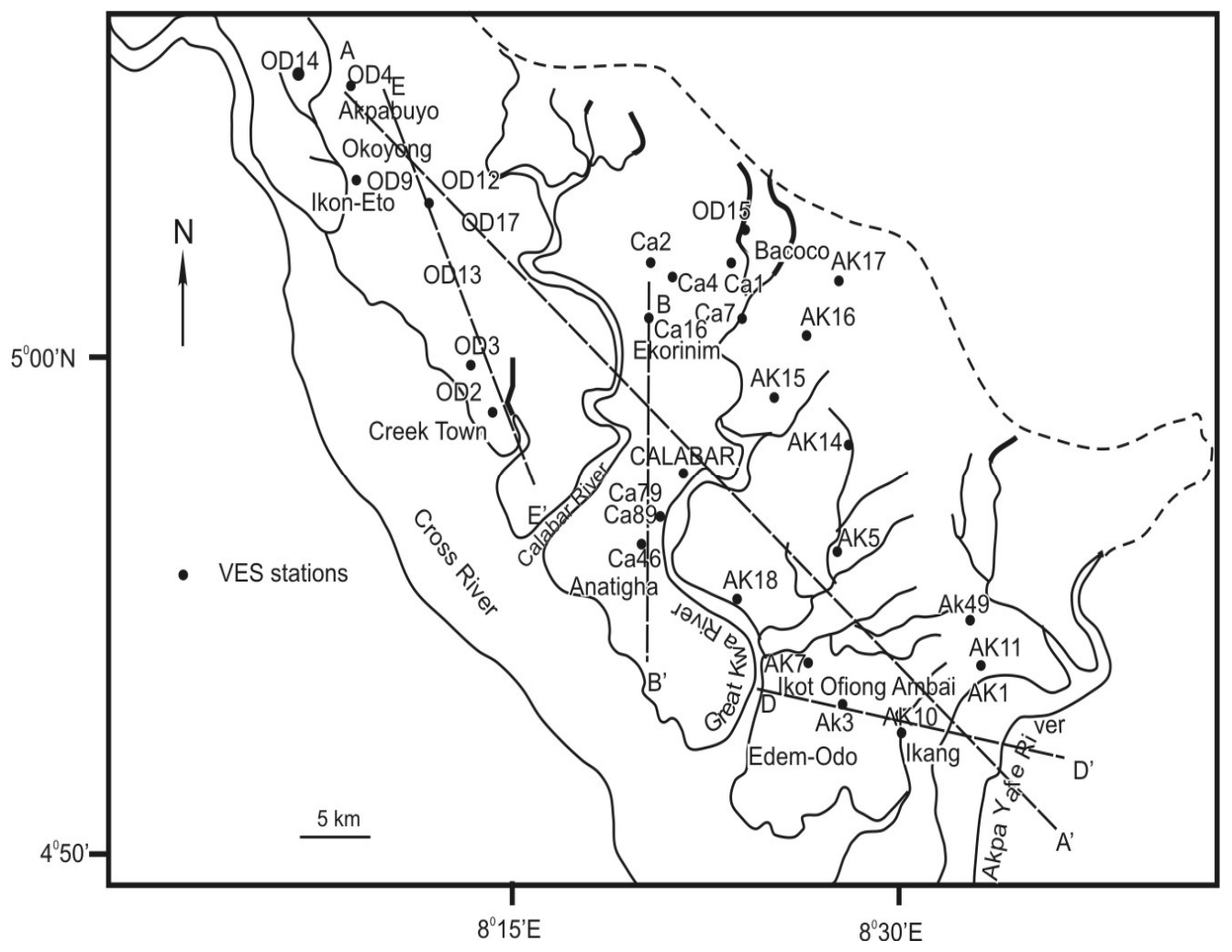

Figure 2. Map of study area including VES/Borehole locations (see Table 1) 
Table 1. GWPI input data for the study area

\begin{tabular}{|c|c|c|c|c|c|c|c|c|c|c|c|c|c|c|}
\hline $\begin{array}{l}\text { Location } \\
\text { Name }\end{array}$ & $\begin{array}{l}\text { Sample } \\
\text { number }\end{array}$ & Lat. N & Long. E & Zone & SWL(m) & $\mathrm{Q}\left(\mathrm{m}^{3} / \mathrm{d}\right)$ & $\begin{array}{c}\mathrm{SC} \\
\mathrm{m}^{3} / \mathrm{d} / \mathrm{m} \\
\end{array}$ & $\mathrm{T} \mathrm{m}^{2} / \mathrm{d}$ & $\begin{array}{l}\text { S (no } \\
\text { unit) }\end{array}$ & $\begin{array}{l}\mathrm{b} \\
(\mathrm{m})\end{array}$ & $\begin{array}{l}\mathrm{FR} \\
\Omega-\mathrm{m} \\
\end{array}$ & $\begin{array}{l}\text { TDS } \\
\mathrm{mg} / 1\end{array}$ & $\begin{array}{l}\mathrm{Cl} \\
\mathrm{mg} / 1 \\
\end{array}$ & $\begin{array}{c}\text { E.Coli } \\
\text { (count/100ml) }\end{array}$ \\
\hline Bacoco & Ca1 & 5.004 .573 & 8021.517 & 1 & 44.3 & 86.4 & 7.7 & 1.6 & $6.00 \mathrm{E}-05$ & 20 & 617 & 195 & 0.05 & 1 \\
\hline Ikot Ekpo & 2 & 5.004 .756 & 8020.793 & 1 & 50.2 & 72 & 51.4 & 75 & - & 27 & 1200 & - & 0.20 & 0 \\
\hline $\begin{array}{l}\text { Ikot } \\
\text { Efangha }\end{array}$ & 3 & 5004.635 & 8021.397 & 1 & 70.1 & 1080 & 32.2 & 301 & $5.20 \mathrm{E}-05$ & 17.5 & 500 & - & 1.00 & 1 \\
\hline $\begin{array}{l}\text { Ikot } \\
\text { Efangha }\end{array}$ & 5 & 5002.161 & 8021.155 & 1 & 70.1 & 2565.2 & 105 & 394 & - & 25 & 1040 & - & 1.40 & 1 \\
\hline $\begin{array}{l}\text { Ikot } \\
\text { Efangha }\end{array}$ & 6 & $5^{0} 02 . .589$ & 8020.55 & 1 & 70 & 1584 & 52.5 & 370 & - & 20 & - & - & 1.20 & 1 \\
\hline $\begin{array}{l}\text { Ikot } \\
\text { Efangha }\end{array}$ & 7 & 5002.221 & 8021.144 & 1 & 69 & 2186 & 58 & 286 & - & 40 & 1250 & 48.6 & 6.40 & 0 \\
\hline $\begin{array}{l}\text { Fed. } \\
\text { Housing }\end{array}$ & 10 & 5002.071 & 8020.627 & 1 & 62.8 & 721.1 & 52 & 1450 & - & 40 & 800 & 233 & 1.20 & 0 \\
\hline $\begin{array}{l}\text { Fed. } \\
\text { Housing }\end{array}$ & 11 & 5002.997 & 804.418 & 1 & 60 & 780 & 67 & 1584 & $1.50 \mathrm{E}-04$ & 45 & - & - & 1.50 & 1 \\
\hline $\begin{array}{l}\text { Fed. } \\
\text { Housing }\end{array}$ & 12 & 5002.82 & 8021.413 & 1 & 62.8 & 721.1 & 52 & 1621 & - & 41 & - & - & 0.40 & 1 \\
\hline Ecorinim & 16 & 5003.203 & 8021.608 & 2 & 5 & 715.2 & 420.7 & 1427 & $1.20 \mathrm{E}-04$ & 40 & 1200 & - & 6.00 & 10 \\
\hline Egerton & 74 & 5001.875 & 8020.151 & 2 & 37.5 & 224.6 & 367.4 & 2406 & - & 30 & 1200 & 289 & 2.30 & 5 \\
\hline Hawkins & 26 & 5000.771 & 8020.042 & 2 & 36.4 & 737 & 103.4 & 1580 & - & 40 & 1290 & - & 5.30 & 2 \\
\hline Edgerly & 76 & 5001.308 & 8020.005 & 2 & 21.6 & 2.76 & 258 & 950 & - & 65 & - & 136.4 & 4.40 & 5 \\
\hline $\begin{array}{l}\text { White } \\
\text { house }\end{array}$ & 78 & 5001.304 & 8020.004 & 2 & 33.2 & 1.2002 & 37.7 & 1456 & - & 41 & 1250 & - & 3.90 & 6 \\
\hline Ediba & 79 & 5001.201 & 8019.814 & 2 & 52.4 & 3135.8 & 84 & 1639.6 & $1.15 \mathrm{E}-04$ & 48 & 1500 & - & 1.20 & 3 \\
\hline Ediba & 80 & 4053.969 & 8019.801 & 2 & 53 & 4363.2 & 545.4 & 1112 & - & 45 & - & - & 5.00 & 4 \\
\hline MCC & 81 & 4059.979 & 8019.895 & 2 & 54 & 4360.5 & 436.3 & 1450 & $1.80 \mathrm{E}-04$ & 60 & - & - & 2.30 & 4 \\
\hline $\begin{array}{l}\text { State } \\
\text { Housing }\end{array}$ & 82 & 501.047 & 8019.895 & 2 & 50.1 & 3069.6 & 194 & 1495 & - & 45 & - & - & 1.30 & 5 \\
\hline $\begin{array}{l}\text { State } \\
\text { Housing }\end{array}$ & 83 & 4059.9 & 8020.069 & 2 & 54 & 4065 & 532.1 & 2240 & $1.50 \mathrm{E}-04$ & 50 & - & - & 5.30 & 6 \\
\hline Atimbo & 84 & 4059.439 & 8020.026 & 2 & 30 & 1562.7 & 58.4 & 2581 & $1.60 \mathrm{E}-05$ & 45 & 1500 & 246 & 6.50 & 7 \\
\hline $\begin{array}{l}\text { Edim } \\
\text { Otop }\end{array}$ & 85 & 4058.695 & 8019.754 & 2 & 23.6 & 115.2 & 6.7 & 2810 & $2.10 \mathrm{E}-03$ & 55 & 1200 & - & 0.98 & 3 \\
\hline Fed. Girls & 86 & 4058.302 & 8019.571 & 2 & 47.1 & 720.2 & 197.2 & 5730 & $3.00 \mathrm{E}-03$ & 50 & 1300 & 243 & 2.40 & 4 \\
\hline UNICAL & 87 & 4056.734 & 8020.895 & 3 & 28.7 & 184.2 & 113.4 & 2595 & - & 48 & 500 & 48 & 2.50 & 0 \\
\hline Anantigha & 46 & 4055.831 & 8020.274 & 3 & 2.3 & 172.8 & 28.5 & 2930 & $2.00 \mathrm{E}-02$ & 45 & 138 & 300 & 2.60 & 0 \\
\hline UNICAL & 71 & 4050.105 & 8033.001 & 3 & 28 & 768 & 258 & 840 & $1.50 \mathrm{E}-04$ & 50 & 360 & - & 3.40 & 0 \\
\hline UNICAL & 72 & 4053.821 & 8024.599 & 3 & 47.9 & 552 & 51.6 & 950 & - & 4.5 & - & - & 3.30 & 1 \\
\hline Goldie & 73 & 4055.915 & 8025.383 & 3 & 40 & 1416 & 93.2 & 560 & $1.80 \mathrm{E}-03$ & 60 & - & - & 6.20 & 2 \\
\hline Eyo Ita & 77 & 4054.601 & 8022.501 & 3 & 20.8 & 2980.8 & 191.2 & 2412 & - & 65 & - & - & 1.50 & 3 \\
\hline Ikang & AK1 & 4052.465 & 8035.45 & 3 & 5.6 & 160.5 & 29.7 & 1180 & $2.10 \mathrm{E}-04$ & 70 & 1620 & 245 & 21.0 & 12 \\
\hline $\begin{array}{l}\text { Ikot Edem } \\
\text { Edo }\end{array}$ & 3 & 4050.056 & 8040.605 & 2 & 27.8 & 184.3 & 18.1 & 2248 & $2.00 \mathrm{E}-03$ & 48 & 450 & 230 & 5.40 & 30 \\
\hline $\begin{array}{l}\text { Ikot } \\
\text { Oyom }\end{array}$ & 7 & 4052.064 & 8045.401 & 2 & 28.9 & 115.2 & 17.3 & 3310 & $9.20 \mathrm{E}-02$ & 50 & 1440 & 230 & 8.50 & 7 \\
\hline $\begin{array}{l}\text { Ikot } \\
\text { Mbakara }\end{array}$ & 9 & 4059.045 & 8015.729 & 2 & 28.2 & 184.3 & 10.5 & 2248.7 & $2.10 \mathrm{E}-03$ & 55 & 1800 & 250 & 1.00 & 4 \\
\hline $\begin{array}{l}\text { Akwa } \\
\text { Obio } \\
\text { Inwang }\end{array}$ & 10 & 5006.376 & 8008.845 & 3 & 31.6 & 172 & 344 & 629.5 & $3.00 \mathrm{E}-03$ & 65 & 120 & 220 & 20.0 & 50 \\
\hline Ikot Ekpo & 11 & 5004.52 & 8009.257 & 3 & 20.5 & 108 & 9.02 & 1156 & $2.20 \mathrm{E}-03$ & 50 & 1250 & 290 & 1.50 & 30 \\
\hline $\begin{array}{l}\text { Creek } \\
\text { Town }\end{array}$ & OD2 & 5010.486 & 8011.279 & 3 & 15 & 161.74 & 770.2 & 4388.2 & - & 40 & 1200 & 200 & 3.00 & 5 \\
\hline $\begin{array}{l}\text { Obom } \\
\text { Itiat }\end{array}$ & OD12 & 5006.385 & 8009.125 & 1 & 2.6 & 184.3 & 158.4 & 3416 & 4.93 & 45 & 1400 & - & 2.40 & 6 \\
\hline Atan Eki & OD13 & 5011.681 & 8009.784 & 1 & 14.2 & 158 & 6.8 & 4.39 & $9.20 \mathrm{E}-04$ & 30 & 1600 & - & 4.50 & 7 \\
\hline Inu Akpa & OD14 & 5004.132 & 8020.423 & 1 & 28.2 & 13070 & 568.3 & 1881.1 & - & 45 & 350 & - & 1.40 & 1 \\
\hline $\begin{array}{l}\text { Okuri } \\
\text { Ikan }\end{array}$ & OD15 & 4056.734 & 8020.895 & 1 & 52.6 & 140.2 & 60.9 & 200.7 & - & 35 & 150 & - & 1.20 & 2 \\
\hline Maximum & & & & & 70.1 & 4363.2 & 770.2 & 5730 & 4.93 & 70 & 1800 & 300 & 21.1 & 50 \\
\hline Minimum & & & & & 2.3 & 72.0 & 6.7 & 1.6 & 0.000016 & 4.5 & 120 & 48 & 0.05 & 0 \\
\hline Mean & & & & & 37.9 & 1373.9 & 165.3 & 1638.7 & 0.0024 & 43.5 & 1008.0 & 212.8 & 3.35 & 6 \\
\hline
\end{tabular}


The VES stations were located to be as close as possible to settlements, but for the urban area, choice of the measurement points was influenced by space and the need to avoid power transmission lines. A maximum current electrode spread of $A B=1000 \mathrm{~m}$ was maintained whenever possible. The apparent resistivity $\left(\rho_{\mathrm{a}}\right)$ was calculated from the Schlumberger electrode array at each station using the relation:

$$
\rho_{\mathrm{a}}=\mathrm{KR},
$$

where $\mathrm{K}$ is the geometric factor and $\mathrm{R}$, the ground resistance.

$\mathrm{K}=\pi \mathrm{MN}\left[(\mathrm{AB} / 2 \mathrm{MN})^{2}-1 / 4\right] . \mathrm{MN}$ and $\mathrm{AB}$ are the potential and current electrode separations respectively. The recorded data were plotted as depth sounding curves and these were qualitatively and quantitatively interpreted. The former involved visual inspection, while the latter was effected by partial curve matching using standard curves and computer iteration techniques. The computer modeled curves are shown in Figure 3. Thirty seven boreholes were also drilled for water supply, providing litho-logic information about aquifers and VES interpretation. Pumping tests were undertaken in wells equipped with submersible pumps. Single hole pumping tests were employed in places where no observation well was available. The data generated in such cases were used for the estimation of the transmissivity of the aquifer. For wells in places where an observation well was available, both transmissivity $\mathrm{T}$ and storativity $\mathrm{S}$, were computed from a semi-log plot of time-drawdown graph (Figure 4). The slope of this graph is equivalent to

$$
\Delta \mathrm{s}=2.3 \mathrm{Q} / 4 \pi \mathrm{T} \text {, hence } \mathrm{T}=2.3 \mathrm{Q} / 4 \pi \Delta \mathrm{s}
$$

Also,

$$
\mathrm{S}=2.25 \mathrm{Tt}_{0} / \mathrm{r}^{2}
$$

Where $\mathrm{Q}=$ pumping rate

$\Delta \mathrm{s}=$ drawdown difference per log cycle of time, $\mathrm{t}$

$\mathrm{t}_{0}=$ time when drawdown is zero

$\mathrm{r}=$ radial distance from a pumping well to an observation well

The combined geo-electric and lithologic sections from VES interpretation and drillers' logs, respectively (Figure 5 ) enable the determination of formation resistivity (FR) variation with depth; thickness (b) and delineation of aquifers and litho-facies or character of aquifer media (L). The specific capacity (SC), depth to water table (or static water level) (SWL), transmissivity (T) and storativity (S) were obtained from the analyses of pumping test data while the bio-chemical tests gave information about water quality based on the presence of Escherichia coli/100ml of water, total dissolved solids (TDS) and chloride contents of the groundwater (Table 1). These parameters are the most important mapable factors which control the groundwater availability and pollution potentials (Amah \& Esu, 2008). Golden software SURFER 8 was used in the development of groundwater potential index (GWPI) maps for the area.

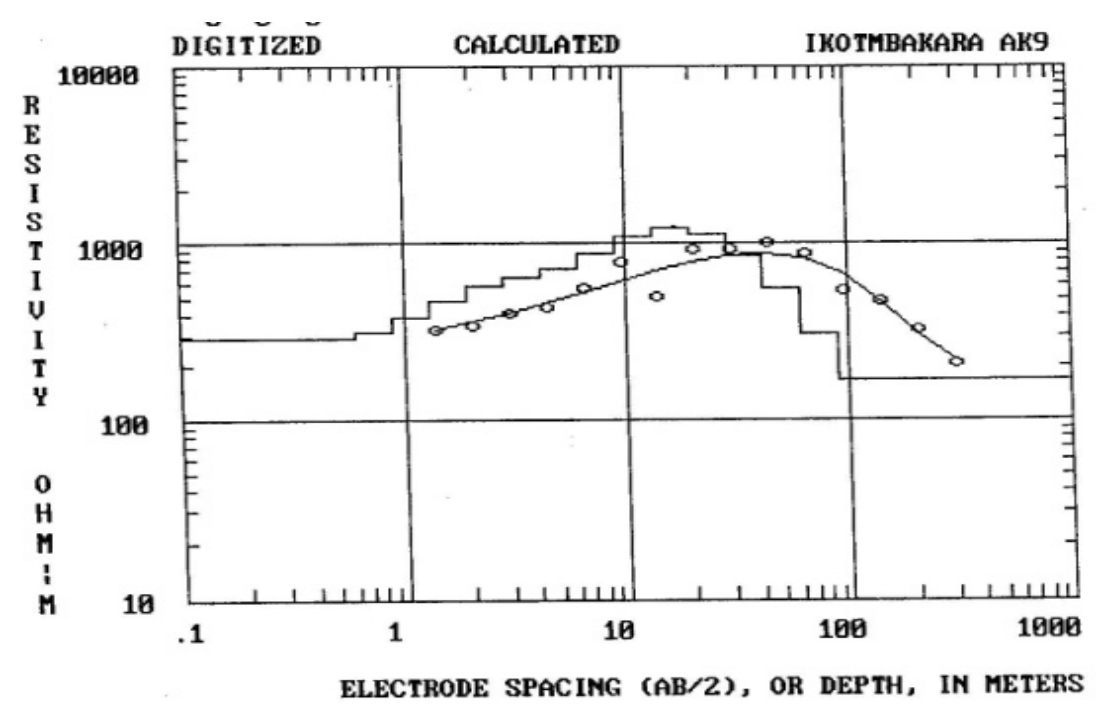

Figure 3. Typical resistivity sounding curves for Ikot Mbakara (AK 9) 


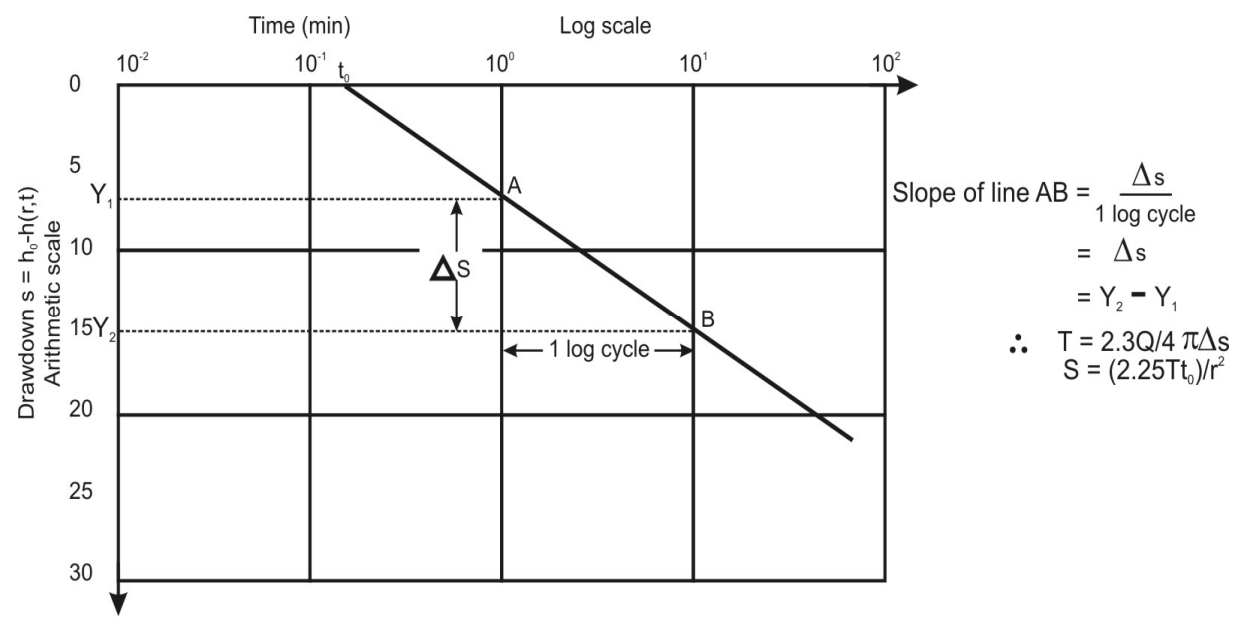

Figure 4. Hypothetical semi-log plot of time- drawdown graph for computation of transmissivity, $\mathrm{T}$ and storativity, $\mathrm{S}$

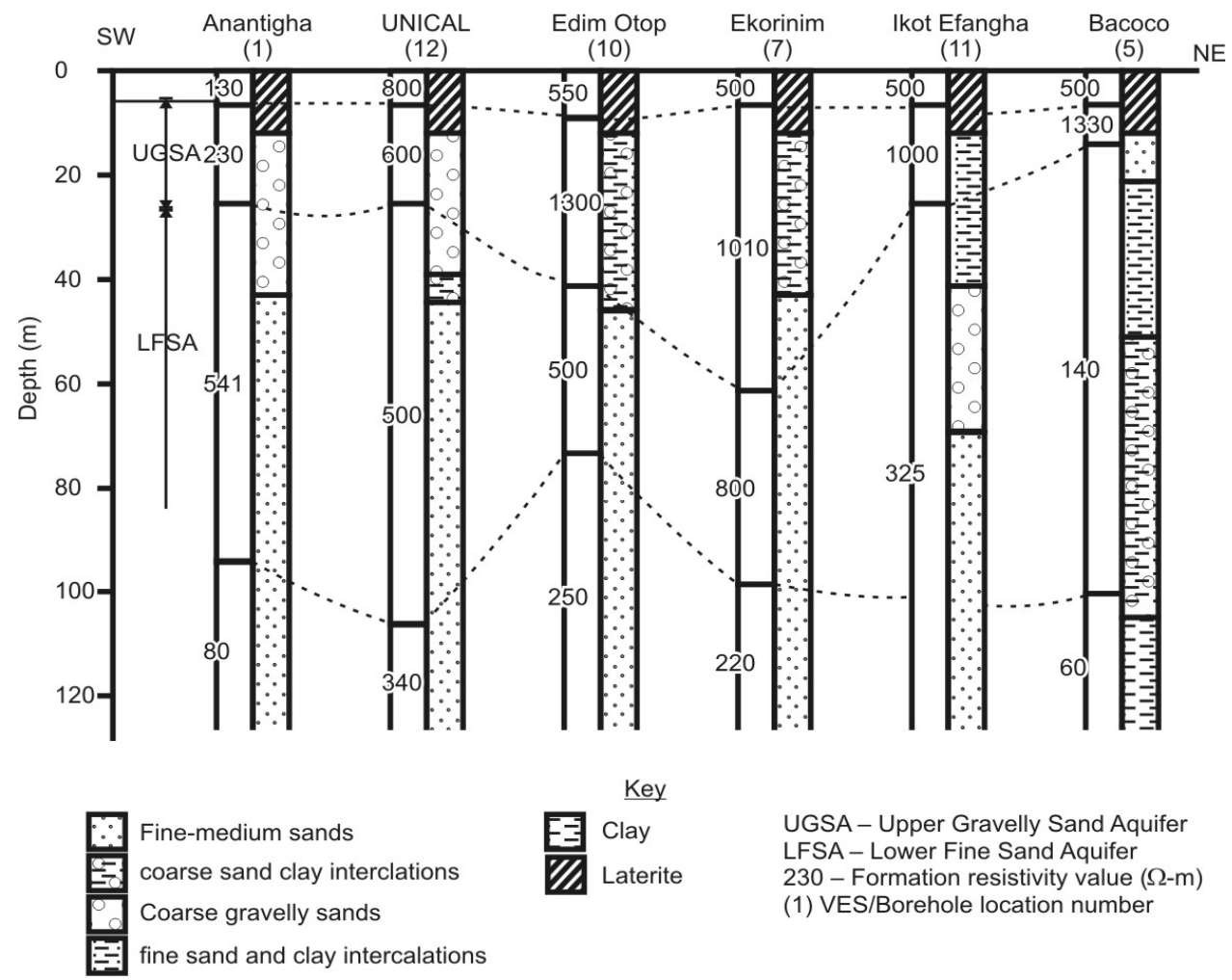

Figure 5. Geo-electic and lithologic sections across parts of the study area

\subsection{Development of GWPI Method}

The method of computing the groundwater potential index GWPI involves three steps. The first step is to assign weights to GWPI parameter, the second is to divide parameter value into ranges and the third is to compute GWPI index.

\subsubsection{Weights}

On the basis of their relative importance in groundwater exploration and evaluation, each GWPI parameter was assigned a weight ranging from 1 to 3 (Table 2). The most significant parameter has a weight of 3 and the least, weight of 1 . Lithofacies (L) and thickness (b) which determine the hydrogeologic properties (porosity and 
permeability) with a weight of 3 were the most significant parameters while $E$. coli and chloride representing the bio-chemical quality of water were given a weight of 1 . These biochemical parameters were given the least weight of 1 due to the filty-plant function of aquifers which asserts that the unsaturated zone overlying an aquifer can act as a waste treatment system (Fetter, 1980).

Furthermore, other important parameters such as static water level (SWL) transmissivity (T), formation resisitivty (FR) total dissolved solids, (TDS) that affect the productivity of an aquifer were assigned a weight of 2 . However storativity $\mathrm{S}$ was given a weight of 1 in this study because certain factors like lithology and stress history show that $\mathrm{T}$ affects productivity of an aquifer more than $\mathrm{S}$ in tight formation (Amah, 2007).

\subsubsection{Ratings}

The GWPI parameters were divided into different class intervals and a rating assigned to each class interval (Table 3 ). The most significant interval has a rating of 3 and the least, a rating of 1 .

\subsubsection{Evaluation of the Groundwater Potential (GWPI) Index}

The groundwater potential index (GWPI) was then computed by taking the sum of the products of weights with rating over all the 10 parameters.

Mathematically,

$$
\text { GWPI }=\mathrm{L}_{\mathrm{w}} \cdot \mathrm{L}_{\mathrm{r}}+\mathrm{b}_{\mathrm{w}} \cdot \mathrm{b}_{\mathrm{r}}+\mathrm{T}_{\mathrm{w}} \cdot \mathrm{T}_{\mathrm{r}}+\mathrm{S}_{\mathrm{w}} \cdot \mathrm{S}_{\mathrm{r}}+\mathrm{SC}_{\mathrm{w}} \cdot \mathrm{SC}_{\mathrm{r}}+\mathrm{WL}_{\mathrm{w}} \cdot \mathrm{SWL}_{\mathrm{r}}+\mathrm{FR}_{\mathrm{w}} \cdot \mathrm{FR}_{\mathrm{r}}+\mathrm{TDS}_{\mathrm{w}} \cdot \mathrm{TDS}_{\mathrm{r}}+\mathrm{Cl}_{\mathrm{w}} \cdot \mathrm{Cl}_{\mathrm{r}}+\mathrm{E}_{\mathrm{w}} \cdot \mathrm{E}_{\mathrm{r}}
$$

Where $\mathrm{w}=$ weight and $\mathrm{r}=$ rating for the different GWPI parameters.

The computed GWPI values are then used to develop a semi quantitative overall rating scale, (R) for the groundwater potential of each zone (Table 4).

From Table $4, R \geq 40$ is considered to be high, $30 \leq R<40$, medium and $R<30$, low groundwater potential (classes $\mathrm{A}, \mathrm{B}$ and $\mathrm{C}$ respectively).

Table 2. Assigned weights to some hydrogeologic parameters

\begin{tabular}{lll}
\hline S/N & Parameters & Weights \\
\hline 1. & Lithofacies, L & 3 \\
2. & Thickness of aquifer, b & 3 \\
3. & Transmissivity, T & 2 \\
4. & Storativity, S & 1 \\
5. & Specific capacpity, SC & 2 \\
6. & Static water level, SWL & 2 \\
7. & Formation resistivity, FR & 2 \\
8. & Total dissoved solid, TDS & 2 \\
9. & Chloride, Cl & 1 \\
10. & Escherichia coli & 1 \\
\hline
\end{tabular}

Table 3. Assigned rating to various catgeories of hydrogeologic parameters

\begin{tabular}{|c|c|c|c|c|}
\hline $\mathrm{S} / \mathrm{N}$ & Parameters & $\begin{array}{c}\text { Very Good } \\
3 \\
\end{array}$ & $\begin{array}{c}\text { Slightly Good } \\
2 \\
\end{array}$ & $\begin{array}{c}\text { Poor } \\
1 \\
\end{array}$ \\
\hline 1 & Lithofaceies L & Coarse sand & Fine sand & Sandy clay \\
\hline 2. & Thickness of aquifer $b, \mathrm{~m}$ & $>50$ & $20-50$ & $<20$ \\
\hline 3. & Transmissivity $\mathrm{T}, \mathrm{m}^{2} \mathrm{~d}^{-1}$ & $>5000$ & $500-5000$ & $<500$ \\
\hline 4. & Storativity S & $>0.005$ & $0.005-0.00005$ & $<0.00005$ \\
\hline 5. & Specific Capacity SC, ${ }^{3}{ }^{3} \mathrm{~d}-{ }^{1} \mathrm{~m}^{-1}$ & $>300$ & $50-300$ & $<50$ \\
\hline 6. & Static Water Levels SWL , m & $<35$ & $35-45$ & $>45$ \\
\hline 7. & Resistivity FR, $\Omega-\mathrm{m}$ & $<500$ & $500-1000$ & $>1000$ \\
\hline 8. & Total Dissolved Solid TDS mgl- ${ }^{1}$ & $<500$ & $500-1000$ & $>1000$ \\
\hline 9. & Chloride $\mathrm{Cl}, \mathrm{mgl}^{-1}$ & $<200$ & $200-600$ & $>600$ \\
\hline 10. & E. coli counts $/ 100 \mathrm{ml}$ & $<2$ & $2-10$ & $>10$ \\
\hline
\end{tabular}


Table 4. Relation between groundwater potential index, GWPI and water potential of a borehole site

\begin{tabular}{lll}
\hline Class & GWPI $(\mathrm{R})$ & Groundwater Potential \\
\hline A & $>40$ & High \\
B & $30-40$ & Medium \\
C & $<30$ & Low \\
\hline
\end{tabular}

\section{Results and Discussion}

The results of GWPI as applied to the entire area of study are presented in Table 5, and Figure 6. The results indicate that all boreholes within the central, southern and northern fall into zones 2, 3 and 1 respectively. This is an indication of high, medium and low ground water potentials.

\subsection{Hydrogeologic Zonation and Ground Water Potential Index Map}

Based on variations in GWPI parameters and the general evaluation chart (Tables 5 and 6), three smaller hydrogeologic settings (zones) have been proposed for the entire Coastal Plain Sands of Calabar and its environs (Figure 6), viz. the northern (zone 1), central (zone 2) and the southern (zone 3).

Table 5. Computed groundwater potential index (GWPI) for some localities within the study area

\begin{tabular}{lllll}
\hline Location & Zones & Local Geology & GWPI & Groundwater Rating \\
\hline Bacoco Ca 1 & & Sandy clay & 29 & Low \\
Ikot Effange Ca 7 & 1 & Lignite & 33 & Medium \\
Federal Housing Ca 10 & & Gravel & 31 & Medium \\
Okurikang OD 15 & North & Interbeds & 29 & Low \\
Obom Itait OD 12 & & & 29 & Low \\
Egerton Ca 74 & & Gravel & 37 & Medium \\
Akpab Okoyong OD & \multirow{2}{*}{ Sentral } & Sand & 40 & Medium \\
Ikot Mbakara AK9 & Lignite & 42 & High \\
Edgerly Ca 76 & & & 41 & High \\
Atimbo Ca 84 & & & 55 & High \\
Fed Girls Ca 86 & & Sand & 30 & High \\
Anantigha Ca 46 & & Gravel & 35 & Medium \\
UNICAL Female Hostel Ca87 & & Clay & 33 & Medium \\
Ikang AK 1 & \multirow{3}{*}{3} & & 31 & Medium \\
Ikot Edem Odo AK 3 & & & 32 & Medium \\
Ikot Oyom Eneyo AK 7 & & & 40 & High \\
Creek Town Pri Sch OD 2 & South & & & \\
\hline
\end{tabular}

\subsubsection{The Central (Zone 2)}

The studies have shown that the central (zone 2) has the highest GWPI rating (40-60) followed by the medium rating of the southern (zone 3) with a GWPI of (30-40). The implication of this rating is that aquifers in the central and southern zones ( 2 and 3 ) are more prolific water bearing than that of northern (zone 1). Moreover, zone 2 is the best area to be targeted for potential groundwater development within the Calabar area. The mean thickness of aquifer, $20<\mathrm{b} \leq 50 \mathrm{~m}$, uniformity in grain sizes (lithofacies $\mathrm{L}$ ) of aquifer materials (gravels and sands) with excellent mean hydraulic parameters $\left(\mathrm{SC}=355.6 \mathrm{~m}^{3} / \mathrm{d} / \mathrm{m}, \mathrm{T}=2640 \mathrm{~m}^{2} / \mathrm{d}, \mathrm{K}=60.4 \mathrm{~m} / \mathrm{d}, \mathrm{Q}=2945 \mathrm{~m}^{3} / \mathrm{d}\right.$ ) and fairly - good bio-chemical quality (Table 6) favor the development of groundwater in this zone.

\subsubsection{The Southern (Zone 3)}

Despite the high saturated thickness of the aquifers $(\mathrm{b}>50 \mathrm{~m})$, moderately high hydraulic parameters $(\mathrm{SC}=150$ $\mathrm{m}^{3} / \mathrm{d} / \mathrm{m}, \mathrm{T}=2150 \mathrm{~m}^{3} / \mathrm{d}, \mathrm{K}=58.5 \mathrm{~m} / \mathrm{d}, \mathrm{Q}=375 \mathrm{~m}^{3} / \mathrm{d}$ ), the groundwater potential of southern (zone 3 ) is not as good as that of central (zone 2). This zone is located near the Atlantic coastline. Its mean static water level, SWL is close to the ground surface $(<17.5 \mathrm{~m})$ and the biochemical quality (Tables $1 \& 6$ ) is poor. This zone is the most highly vulnerable to surface and near surface contamination (Edet, 2004). The contamination is due to a wide variety of 
human activities such as bad practices of waste disposal methods from both domestic and industrial sources as indicated by the presence of E-Coli (3-50 counts/100 ml) above the World Health Organisation (WHO, 2001) standard $(<1$ count $/ 100 \mathrm{ml})$, thereby making groundwater unsuitable for drinking and domestic purposes. In addition, there is possibility of salt water intrusion into the aquifers in this zone in the nearest future, therefore this should be monitored.

\subsubsection{The Northern (Zone 1)}

The northern zone has a low groundwater potential and the least vulnerability potential. This zone may pose serious problems for future groundwater development. This zone marks the transitional boundary between the clastic sedimentary rocks of the Benin Formation (Tertiary to Recent) and the argillaceous sediments of the Calabar Flank (Early to Middle Cretaceous). There is a rapid lithofacies (L) change in zone 1 between gravely sand interbeds and clays. Moreover the aquifers in this zone are thin $(b<20 \mathrm{~m})$, lie at great depths with a mean static water level $\mathrm{SWL} \geq 45.5 \mathrm{~m}$ in comparison with the other two zones (Figure 6). Though the biochemical quality is good (not highly vulnerable to surface contamination) its hydraulic properties $\mathrm{SC}=52.1 \mathrm{~m}^{3} / \mathrm{d} / \mathrm{m}, \mathrm{T}=750 \mathrm{~m}^{2} / \mathrm{d}, \mathrm{K}=$ $48 \mathrm{~m} / \mathrm{d}, \mathrm{Q}=295 \mathrm{~m}^{3} / \mathrm{d}$ ) are low in comparison with the aquifers in the central and southern zones (Table 6).

Table 6. Aquifer rating and ground water potential of the study area

\begin{tabular}{|c|c|c|c|c|c|c|c|c|c|}
\hline Zone & Lithofacies & $\begin{array}{l}\text { Aquifer } \\
\text { thickness b } \\
\text { (m) }\end{array}$ & $\begin{array}{l}\text { Mean Hydraulic } \\
\text { parameters }\end{array}$ & $\begin{array}{l}\text { Mean } \\
\text { static water } \\
\text { level SWL } \\
\text { (m) }\end{array}$ & $\begin{array}{l}\text { Bio-physicochemical } \\
\text { quality }\end{array}$ & $\begin{array}{l}\text { Aquifer } \\
\text { type }\end{array}$ & $\begin{array}{l}\text { Aquifer } \\
\text { rating }\end{array}$ & $\begin{array}{l}\text { Ground } \\
\text { water } \\
\text { potential }\end{array}$ & Remarks \\
\hline North & $\begin{array}{l}\text { Sands, clays, } \\
\text { lignite gravel } \\
\text { and shales }\end{array}$ & $<20$ & $\begin{array}{l}\mathrm{T}=750 \mathrm{~m}^{2} / \mathrm{d} \\
\mathrm{K}=46 \mathrm{~m} / \mathrm{d} \\
\mathrm{S}=0.00045 \\
\mathrm{Q}=795.0 \mathrm{~m}^{3} / \mathrm{d} \\
\mathrm{SC}=52.1 \\
\mathrm{~m}^{3} / \mathrm{d} / \mathrm{m}\end{array}$ & 45.5 & 1 & $\begin{array}{l}\text { LFSA } \\
\text { and } \\
\text { UGSA }\end{array}$ & 3 & 3 & Low \\
\hline Central & $\begin{array}{l}\text { Gravel, sand, } \\
\text { lignite, } \\
\text { clay }\end{array}$ & $20<b<50$ & $\begin{array}{l}\mathrm{T}=2150 \mathrm{~m}^{2} / \mathrm{d} \\
\mathrm{K}=60.4 \mathrm{~m} / \mathrm{d} \\
\mathrm{S}=0.0009 \\
\mathrm{Q}=2945 \mathrm{~m}^{3} / \mathrm{d} \\
\mathrm{SC}=355.6 \\
\mathrm{~m}^{3} / \mathrm{d} / \mathrm{m}\end{array}$ & 35.8 & 2 & $\begin{array}{l}\text { UGSA } \\
\text { and } \\
\text { LFSA }\end{array}$ & 1 & 1 & High \\
\hline South & $\begin{array}{l}\text { Gravel, } \\
\text { sand and clay }\end{array}$ & $>50$ & $\begin{array}{l}\mathrm{T}=2640 \mathrm{~m}^{2} / \mathrm{d} \\
\mathrm{K}=58.5 \mathrm{~m} / \mathrm{d} \\
\mathrm{S}=0.0015 \\
\mathrm{Q}=375 \mathrm{~m}^{3} / \mathrm{d} \\
\mathrm{SC}=150.0 \\
\mathrm{~m}^{3} / \mathrm{d} / \mathrm{m}\end{array}$ & 17.5 & 3 & $\begin{array}{l}\text { UGSA, } \\
\text { LFSA }\end{array}$ & 2 & 2 & Medium \\
\hline
\end{tabular}

UGSA-Upper gravelly sand aquifer

LFSA-Lower fine sand aquifer

1-Good; 2-Fairly Good; 3-Fair

\subsection{GWPI Vulnerability Map}

The computed GWPI map (Figure 6) was also made to serve as a vulnerability potential map for the study area. The resulting map indicates that the northern (zone 1) has the least groundwater availability and pollution potential $($ GWPI $<30$ ). The central (zone 2) has a high GWPI $>40$, but medium pollution potential while the southern (zone 3 ) is a region with a medium GWPI, but a high pollution potential. Thus, groundwater contamination zone lies entirely between the southern (zone 3) and some parts of central (zone 2) with the GWPI ranging from 30 to 40.This is also in agreement with the work of Edet (2004) who concluded that the upper aquifer in the south was more vulnerable to surface contaminants than the lower (deeper) aquifer in the north of the study area. 


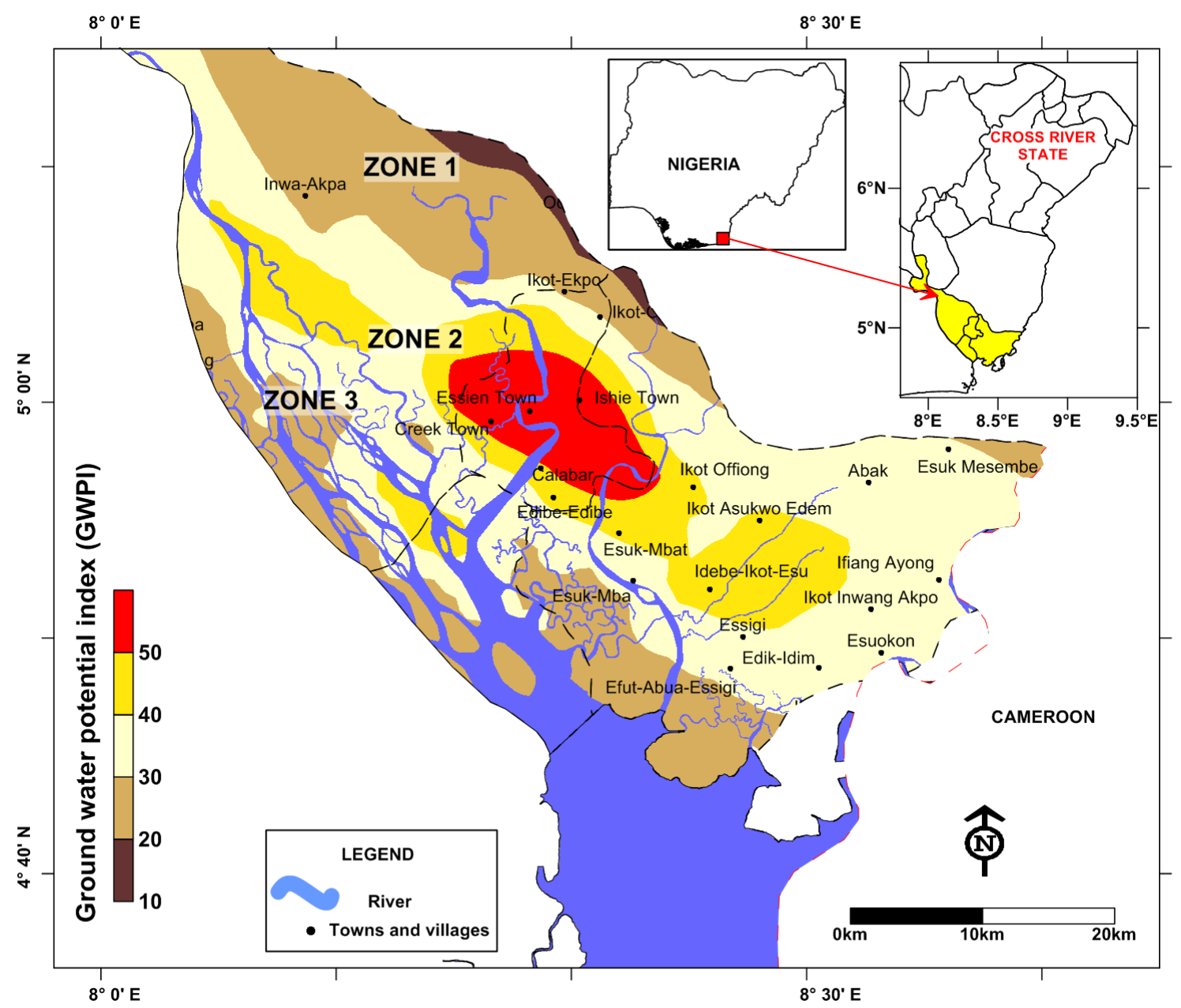

Figure 6. Zonation and ground water potential index (GWPI) map

\section{Conclusion}

The groundwater site evaluation model and quality assessment based on GWPI have been developed for the Calabar area. The procedure used in this study is similar to that of aquifer vulnerability techniques described for DRASTIC and CALOD. However, GWPI is modified to map both areas of groundwater availability and pollution potential in using simple and readily available data from driller logs and field measurements.

The results of GWPI have enabled the demarcation of Coastal Plain Sands of the Calabar area into smaller hydro geologic zones suitable for detailed pollution studies: northern zone (areas of low GWPI; least pollution potential), central zone , (areas of high GWPI, medium pollution potential) and southern zone (areas of medium GWPI, but high pollution potential).

The most important parameters which contribute to water availability include lithofacies (L), saturated aquifer thickness (b), static water level (SWL), transmissivity (T) and storativity (S); while E-coli, chloride $\left(\mathrm{Cl}^{-}\right)$and static water level (SWL) remain the most significant parameters that will influence the ground water pollution in the southern zone of the study area.

Groundwater quality deterioration in coastal aquifers is due to poor management of human waste-disposal and saltwater intrusion. These factors will combine to limit the availability of potable water for domestic and industrial uses in the nearest future and should be monitored.

\section{References}

Aller, L., Bennet, T., Lehr, J. H., \& Petty, R. J. (1987). DRASTIC: a standardized system for evaluating groundwater pollution potential using hydrogeologic settings. EPA/600/2-87/035 US Environmental Protection Agency, Washington DC. 455p. 
Amah, E. A. (2007). Geophysical and pumping test analyses of groundwater resources of Calabar and its environs. Unpublished Ph.D thesis of the Department of Geology, University of Calabar, 214p.

Amah, E. A., \& Esu, E. O. (2008). Geophysical and hydrogeological studies of shallow aquifers of Calabar area, South-eastern Nigerian. International Journal of Environmental Sciences, 4(2), 78-90.

American Public Health Association (APHA). (1989). Standard methods for examination of water and waste water (17th ed.). Washington DC.

Edet, A. E. (1993). Hydrogeology of parts of Cross River State, Nigeria: Evidence from aero-geological and surface resistivity studies. Unpublished Ph.D Thesis of the Department of Geology, University of Calabar, 350 p.

Edet, A. E., \& Okereke, C. S. (2002). Delineation of shallow groundwater aquifers in the Coastal Plain Sands area (Southern Nigeria) using surface resistivity and hydrogeological data. Journal of African Earth Sciences, 35, 433-443. http://dx.doi.org/10.1016/S0899-5362(02)00148-3

Edet, A. E. (2004). Vulnerability evaluation of a coastal plain sand aquifer with a case example from Calabar, South Eastern Nigeria. Environmental Geology, 45, 1062-1070.

Esu, E. O., \& Amah, E. A. (1999). Physico-chemical and bacteriological quality of natural water in parts of Akwa Ibom and Cross River States Southern Nigeria. Global Journal of Pure and Applied Sciences, 5(4), 525-534.

Fetter, C. Jr. (1980). Applied Hydrogeology. Columbus, Ohio: CE. Messill publishing company. 488p.

Ileoje, N. P. (1991). A New geography of Nigeria Longman, Nigeria.

Okereke, C. S., Esu, E. O., \& Edet, A. E. (1998). Determination of ground water sites using geological and geophysical techniques in the Cross River State, South-eastern Nigeria. Journal of African Earth Sciences, 27(1), 149-163. http://dx.doi.org/10.1016/S0899-5362(98)00053-0

Okon-Umoren, O. E. (1999). Geophysical studies of the Calabar Flank of South - Eastern. Unpublished Ph.D Thesis, Department of physics, University of Calabar, 360p.

Short, K. C., \& Stauble, A. J. (1967). Outline Geology of Nigeria Delta. American Association of Petroleum Geologist, 51, 761-779.

World Health Organization. (2001). Drinking water Guidelines Geneva. 